\title{
Spiritual Maturity and the Appropriate Age for a Bishop in Auxentius of Durostorum
}

\author{
Hiroshi Tone | ORCID: 0000-0003-4159-0986 \\ PhD Candidate, Doshisha University, Kyoto, Japan \\ egn1104@mail2.doshisha.ac.jp
}

\begin{abstract}
Epistula de Wulfila episcopo by Auxentius of Durostorum reported that Ulfila became a bishop when he was thirty years old. This report was dramatized in order to emphasize Ulfila's sanctity. This study will examine the symbolic meaning of thirty years old, and explain how it is a deep-rooted and continual idea in the arrangement of clerical offices. As a result, I contend that the symbolism of "thirty years old" was the appropriate age for someone to lead the community. This idea came from Numbers 4:2-3 and could be also found in the Judaic tradition. One could argue that this idea on spiritual leadership prevailed, was accepted and was later the basis of the clerical offices.
\end{abstract}

\section{Keywords}

Auxentius of Durostorum - spiritual maturity - the appropriate age - the promotion to a bishop

If we investigated a bishop's Curriculum Vitae in late antiquity, we might be surprised to find that bishops came from a wider variety of backgrounds. For example, Alexander, the bishop of Comana, was a coal burner; George, the Arian bishop of Alexandria, was born in the shop of fuller; Spyridon, the bishop of Trimithous, was a shepherd; and Zeno, the bishop of Maiouma, was a 
linen weaver. ${ }^{1}$ This fact leads us to presume that the assignment of the clerical offices should consider candidates' various ages, former offices, characters, etc.

Scholars often discussed both the arrangement of clerical offices into a hierarchy and the promotion from one order to another. Some ancient sources reported that men had to progress through several stages before they could be ordained as a bishop, and things such as his age, marital status, and how he lived his daily life were considered. ${ }^{2}$ On the other hand, some candidates bypassed this sequential order and became bishops without following the regular procedure. One of the famous examples is Ambrose of Milan's rapid promotion in $374,{ }^{3}$ which Palladius of Ratiaria criticized as an exploitation of the order of clerical offices. ${ }^{4}$ Palladius noticed that other promotions to bishop, in which Ambrose was involved, were also in disorder and corrupted. ${ }^{5}$ Contemporary church leaders found that there were other similar cases in which someone received a promotion even though they were unprepared for such a role. ${ }^{6}$ We, therefore, argue that such a problem could be the reason why there was a reconsideration for clerical orders inside the Church. ${ }^{7}$

1 C. Rapp, Holy Bishops in Late Antiquity: The Nature of Christian Leadership in an Age of Transition, Berkley, 2005, p. 177.

2 G. D. Dunn explained three examples by examining Siricius' letter, Innocent I's letter and Zosimus' letter (G. D. Dunn, 'The Clerical Cursus Honorum in the Late Antique Roman Church,' Scrinium vol. 9 (2013), pp. 121-132.).

3 T. D. Barnes regarded Ambrose's status before his election, as "... a noble impoverished by the loss of his father's wealth ..." (T. D. Barnes, "The Election of Ambrose of Milan," in: Episcopal Election in Late Antiquity, ed. J. Leemans, P. van Nuffelen, S. W. J. Keough and C. Nicolaye, Berlin, 2011, p. 48.). Barnes also explained that becoming a bishop for Ambrose was “... a way out of his predicament ..." (p. 52.) to make his marks in the world.

4 Make a reference to one part of Fragment d'une apologie des condamnés d'Aquilée in Scolies Ariennes sur le Concile d' Aquilée: "... sed amicali gratia suffragio t[..] humano passim creareris indigne." (Fol. 343v 3-4.).

5 See, on this point, Fragment d'une apologie des condamnés d'Aquilée in Scolies Ariennes sur le Concile d'Aquilée: “... Denique ex tuo tam uo [..]li[...] merito etiam aliena merita te pensasse aduerte, quippe qui tam leuis tamque facilis in illorum iniuriam extitisti, utputa temere ac sine ullo examine destruendum esse sacerdotium, quam facilem ac passiuam et non libratam expertus es aedificationem tuam." (Fol. 343v 4-17).

6 Dunn suggested other similar cases: "Well before Ambrose, the Council of Nicaea in 325 had banned the ordination of neophytes as bishops, so the issue was not new and not confined to Rome. Certainly the Synod of Sofia (ancient Serdica in the province of Dacia Mediterranea) in 343 had legislated that wealthy individuals and those with a background in civil administration needed to advance through clerical ranks from lector to deacon to presbyter to bishop in order that someone be tested and found worthy." (Dunn, 'The Clerical Cursus Honorum,' p. 126.).

7 For example, Dunn presumed that “... Ambrose's rapid promotion in 374 (not any concern about his martial situation) might have triggered the church of Rome thinking about this issue in the Italian context ..." (Dunn, 'The Clerical Cursus Honorum,' p. 125.). 
In late antiquity, the Church leadership ruled that promotion to the bishopric required certain qualifications. With regard to this point, G. D. Dunn primarily examined Innocent I's letter in which he indicated formal conditions for promotions: the consent of more than one metropolitan bishops, ${ }^{8}$ the prohibition for a bishop to hold civil office, ${ }^{9}$ and the ineligibility for a bishop to marry a previously married women or for himself to marry a second time. ${ }^{10}$ It is important to note that in Innocent I's letter, he did not discuss any requirement of an internal condition of spiritual maturity. ${ }^{11}$ On the other hand, those who held the position of bishop were understood to have a special spiritual maturity. For example, the ecclesial leadership of the bishop has been often compared to Moses as the biblical model par excellence. C. Rapp has collected a number of sources where bishops themselves invoked Moses as their predecessor and the precedent for their own actions. ${ }^{12}$ Rapp explained that the reason Moses was such a suitable model for bishops was because "... the evolution of his [sc. Moses'] life in three stages, each exactly forty years in length ..."13 namely "... a sequence of education, contemplation, and ministry."14 According to Rapp, these three phases in Moses' career provided a biographical pattern with which many bishops of the fourth and fifth centuries could identify. ${ }^{15}$ This, in addition to the abovementioned sources that Dunn examined, leads us to question whether the proposals that outlined the arrangement of clerical offices was influenced by the desire for a bishop to be spiritually mature.

This study will investigate this question through an examination of the testimony of the fourth-century Auxentius of Durostorum in his Epistula de Wulfila episcopo. Scholars have rarely employed Auxentius' testimony while discussing the arrangement of clerical offices. This may be because scholars, up to this point, have assumed that Auxentius only recorded Ulfila's chronology. The first part of this paper will utilize R. Gryson's work to overturn this presumption about Auxentius' work and to discuss his dramatization of Ulfila's life. Subsequently, I will explain the symbolic meaning of "spiritual maturity" and the appropriate age of a bishop in Auxentius' work. The second part of this

8 G. D. Dunn, "Canonical Legislation on the Ordination of Bishops: Innocent I's Letter to Victricius of Rouen," in: Episcopal Election in Late Antiquity, ed. J. Leemans, P. van Nuffelen, S. W. J. Keough and C. Nicolaye, Berlin, 2011, pp. 155-159.

9 Dunn, "Canonical Legislation," pp. 159-162.

10 Dunn, "Canonical Legislation," pp. 162-164.

11 It should be noted that the deuteron-Pauline letters have already dealt with the personal and professional qualities in positions of leadership and ministry.

12 Rapp, Holy Bishops, pp. 127-129.

13 Rapp, Holy Bishops, p. 132.

14 Rapp, Holy Bishops, p. 132.

15 Rapp, Holy Bishops, p. 132. 
paper will develop Gryson's studies and argue for the importance of Auxentius' testimony which was recorded prior to other ancient sources such as letters of the Roman bishops Siricius and Innocent I. We can presume, then, that ideas about spiritual leadership similar to Auxentius' testimony were already prevalent and had been accepted even before the legal conditions to become a bishop were systematically codified later. The second part of this paper thus examines the roots of Auxentius' perspective and uncover the influence of Old Testament ideas about aging on the promotion of a churchman to the position of bishop.

The Epistula de Wulfila episcopo was included in Scolies Ariennes sur le Concile d'Aquilée, which was registered on the margins of Codex Paris 8907. This codex was discovered in a French monastery at the end of the 18 th century. ${ }^{16}$ The first researchers who studied Auxentius' report about Ulfila (?-383) were scholars of German studies who began to study it as an important source on the origins of the Germanic tribes. ${ }^{17}$

In his Epistula de Wulfila episcopo, Auxentius recorded the doctrine and the life of Ulfila who was Auxentius' mentor in Christianity. There has been a great deal of discussion about Ulfila's Arian doctrine in the late antique period. ${ }^{18}$ The historical record of Ulfila's missionary work in the Gothic tribes became the focus of debate among the researchers of German studies. ${ }^{19}$ For this study, the pertinent matter is Auxentius' report on Ulfila's progression through the clerical offices to his promotion to bishop.

Auxentius tells us that Ulfila became a bishop when he was thirty years old, and he held this office for forty years, until his death at the council in Constantinople in 383 . This description seems, on the surface, to simply be a report of Ulfila's life. However, we should note that, according to Gryson, it is possible to dramatize this description of Ulfila's life in such a way that emphasizes Ulfila's sanctity. According to Philostorgius' Ecclesiastical History, Ulfila became a bishop in 341 and, if the biography is accurate, Ulfila died in 381 when

16 F. Kauffmann, Aus der Schule des Wulfila, Strassburg, 1899, S. Xv.

17 See H. C. Brennecke, "Deconstruction of the so-called Germanic Arianism," in: Arianism: Roman Heresy and Barbarian Creed, Farnham, 2014, p. 129.

18 R. Gryson, Scolies Ariennes sur Le Concile d'Aquilée - Introduction, Texte Latin, Traduction et Notes, Edition du Cerf, 1980, pp. 173-204.

19 Gryson, Scolies Ariennes, pp. 143-165. 
he was seventy years old, which was inconsistent with the fact that no one of Arian was invited at the council of Constantinople in $381 .^{20}$

Gryson highlighted here that Auxentius' report on Ulfila's chronology corresponded to Biblical themes: the age of thirty years old when Ulfila became a bishop, was the same as that of David when he succeeded the throne, Joseph when he became a Vizier, and Jesus Christ when he began to mission. ${ }^{21}$ However, Gryson provided us with evidence ${ }^{22}$ that Ulfila served as a bishop for forty years, the same span David's reign. ${ }^{23}$ Further, if we consider Auxentius' dramatization, it becomes clear that Auxentius did not record the factual age of Ufila when he became a bishop. We must, then, ask why Auxentius chose to make this change to Ulfila's biographical information.

We can find simple solutions to these problems through an examination of the Biblical correspondence in Auxentius' letter. Auxentius mentioned Ulfila's responsibilities as a bishop: "in order that Ulfila could rule, correct, teach, and improve the Gothic tribe." ${ }^{24}$ Subsequently, Auxentius argued that this responsibility was the same as that of David, Joseph, ${ }^{25}$ and Jesus Christ: "Just as holy David succeed to the throne and received a prophecy at thirty years of age to rule and teach God's people and offspring of Israel ..."; ${ }^{26}$ "Just as our Master and God Jesus Christ was baptized at thirty years old and began to preach the Gospel and feed human spirits ..."27 These Biblical references lead us to argue that Auxentius believed that the role of a bishop was to rule, teach, and improve believers according to Biblical figures. Therefore, he changed the age of Ulfila so that it was the same as David, Joseph, and Jesus Christ. This means that, from Auxentius' perspective, the spiritual maturity of a bishop was linked to the appropriate age for a bishop in a symbolic way. A bishop should govern diverse the opinions of people inside the church and, simultaneously, he should defend against enemies outside of the church, both of which required the experience of age and progression through the clerical ranks.

\footnotetext{
20 Gryson, Scolies Arienne, p. 160.

21 Gryson, Scolies Arienne, p. 161.

22 Gryson, Scolies Arienne, p. 161.

23 Gryson, Scolies Arienne, p. 161.

24 See: "... ut regeret et corrigeret et doceret et aedificaret gentem Gothorum ..." (Fol. 306v $3^{6-37 .) \text {. }}$

25 It is impossible to decipher the part of the description on Joseph (Fol. 306v 40-Fol. 307r 1.).

26 See: "Vt quemadmodum s(an)c(tu)s Dauid triginta annorum rex et profeta est constitutus, ut regeret et doceret populum Dei et filios Hisdrael ..." (Fol. 306v 34-35.).

27 See: "Et quemadmodum d(omi)n(u)s et d(eu)s noster $\mathrm{Ih}($ esu $)$ s $\mathrm{Cr}($ istu $)$ s Filius $\mathrm{D}(\mathrm{e})$ i triginta annorum secu[n]dum carnem constitutus et baptizatus coepit Euangelium predicare et anim[as] hominum pascere ..." (Fol. 307r 1-3.).
} 
Auxentius cited famous Biblical figures from Genesis 41:46, 2 Samuel 5:4 and Luke 3:23. These three Biblical passages attached great importance to the age of thirty years. This leads us to seek what special meaning this age beholds in the Bible. It is relevant here to note that both C. Westermann ${ }^{28}$ and J. Ebach ${ }^{29}$ argued that Genesis 41:46 $6^{30}$ was influenced by Numbers 4:2-3. ${ }^{31}$ Both materials were derived from the same origin of the Priestly sources in the Documentary hypothesis. The Documentary hypothesis posits that the Torah is a compilation of four originally independent sources: the Jahwist, Elohist, Deuteronomist, and Priestly sources. In the same respect, A. A. Anderson indicated in his commentary on 2 Samuel that 2 Samuel $5: 4^{32}$ was related to the verses from Numbers. ${ }^{33}$ In addition to this, D. G. Firth argued that because 2 Samuel was entangled with the theological interests of the establishment of God's relationship with Israel, it is conceivable that 2 Samuel 5:4 was dependent upon Numbers 4:2-3. ${ }^{34}$ The discussion turns to the origin of Luke 3:23 which tells us that Jesus was thirty years old when he began to preach the gospel. G. Theissen and A. Merz pointed out that Luke 3:23 could be based upon David and Joseph in the Old Testament. ${ }^{35}$

These discussions of Genesis 41:46, 2 Samuel 5:4 and Luke 3:23 allow us to argue that references to "thirty years old" in these Biblical passages were hounded on Numbers 4:2-3. In Numbers 4:2-3, thirty was the age at which the Levites began to guide the holy community, and it becomes clear that the special meaning of this age for Levites influenced descriptions about the age of David and Joseph when they began to rule, and of Jesus Christ when he began to lead the Christian community. The special meaning of this age in the Old Testament was prevalent for many years and, for example, in the fourth century, Auxentius compared Ulfila's age when he became a bishop, with these three Biblical figures. We can argue from this that Auxentius' perspective on the special meaning of thirty years old originally derived from Numbers $4: 2-3$

28 C. Westermann, Genesis: a Commentary, trans. J. J. Scullion, London, 1984-1986, p. 96.

29 J. Ebach, Genesis 37-50, Freiburg, 2007, p. 245.

$30 \quad$ See "And Joseph was thirty years old when he stood before Pharaoh king of Egypt."

31 See "... Take the sum of the sons of Kohath from among the sons of Levi, by their families, by their father's houses, from thirty years old and upward even until fifty years old, all that enter upon the service, to do the work in the tent of meeting."

32 See "David was thirty years old when he began to reign ..."

33 A. A. Anderson, 2 Samuel, Dallas, 1989, p. 77.

34 D. G. Firth, 1\&2 Samuel, Nottingham, 2009, p. 21.

35 G. Theissen and A. Merz, the Historical Jesus: A Comprehensive Guide, Minneapolis, 1998, p. 156 . 
and its later versions in other Biblical passages. In other words, Auxentius' perspective on spiritual leadership was a deep-rooted idea based on the Bible.

The perspective of the Judaic tradition also supported the importance of Auxentius' testimony. In the Old Testament, there are many metaphors and allusions to the various stages of human life, from which the Judaic tradition developed ideas about aging. Among such thoughts, G. A. Kohut pointed out that the computation of fifteen year increments for each period of life became very popular. ${ }^{36}$ Scholars argue that this idea originated from a part of the Mishnah, Avot, v. 21: “... Fifteen [is the age] for [the study of] Talmud ... Thirty [is the age] for [full] strength ..." ${ }^{37}$ If we examine several major commentaries on the Mishna, Avot, v. 21, it becomes clear that some commentators interpreted the meaning of thirty years old. The Midrash Shmuel, an aggadic Midrash on Samuel, ${ }^{38}$ noted that the ability to guide and influence others for good was linked to the age of thirty years, when one had finished their study. ${ }^{39}$ This leads us to believe that this age symbolized the starting point at which one could begin to preach God's will and guide the community.

It is important to note that according to an annotation from the fifteenthcentury Italian rabbi Bartenura, thirty years old was the age at which Levites could begin their service in the temple. Bartenura commented: "As the Levites would put up and take down the Tabernacle and load the cars and carry on their shoulders from [the age] of thirty and above." ${ }^{40}$ W. O. E. Osterley ${ }^{41}$ and A. Cohen ${ }^{42}$ noted in their commentaries on the Midrash that it is reasonable that Bartenura's annotation was consistent with Numbers 4:2-3. We can observe from this annotation that, the Judaic tradition, the symbolic meaning of thirty years was as the starting point for guiding the community and had its foundation in Numbers. We can then compare it with Auxentius' perspective and to argue that Auxentius' perspective followed a deep-rooted idea from the

36 G. A. Kohut, "Ages of man," in: the Jewish Encyclopedia vol. 1, 1901, p. 234.

37 Aboth, translated into English with notes, glossary and indices by J. Israelstam, under the editorship I. Epstein, London, 1988, p. 15 a.

38 W. O. E. Osterley explained that "The Midrash Shemuel is a late work belonging to the first half of the eleventh century, and there are interpolations of still later date. Of the thirty-two sections into which the work is divided, only the last eight deal with the second book of Samuel, all the rest being concerned with the first book." (W. O. E. Osterley and G. H. Box, A Short Survey of the Literature of Rabbinical and Medieval Judaism, London, 1920, p. 72.)

39 https://www.sefaria.org/Midrash_Shmuel_on_Avot.5.21?lang=bi (2018/8/23).

40 https://www.sefaria.org/Bartenura_on_Pirkei_Avot.5.21?lang=bi (2018/8/23).

41 W. O. E. Osterley, The Sayings of The Jewish Fathers, London, 1919, p. 73.

42 A. Cohen, Aboth, translated into English with notes, glossary and indices by J. Israelstam, under the editorship I. Epstein, London, 1988, p. 15a (note f. 7.). 
Old Testament and that it was prevalent and accepted both before and after the systematization of the clerical offices.

\section{$4 \quad$ Conclusion}

We conclude that Auxentius' testimony could be utilized as evidence that the proposal for the arrangement of clerical offices was influenced by the perceived need for an internal qualification: that the appropriate age to become a bishop was thirty years old. This age had a special meaning related to the spiritual maturity needed in order to guide and rule the holy community, an idea that was derived from Numbers $4: 2-3$. The beliefs that guided ideas about who was an appropriate candidate for bishop were part of deep-rooted thoughts on spiritual leadership, in which we can find similarities between the Christian and Judaic traditions.

This conclusion shows us that late antique church leaders could understand the role of a bishop not only from the perspective of a famous symbolic figure such as Moses, but also from the nature of the leadership in the Bible. Our argument also develops Gryson's studies on the symbolic meaning of thirty years old and uncovers the importance of Auxentius' testimony which predate other ancient sources on the clerical offices. Namely, Auxentius's perspective on spiritual leadership was already prevalent and widely believed before the clerical arrangements to a bishop were codified. This is important when we consider the general picture of clerical arrangements in late antiquity. I hope that this study will contribute to a better understanding of the qualifications, image, and role of the bishop in late antiquity. 